DOI: $10.19195 / 2084-5065.39 .6$

\title{
Karnoprocesowa ochrona małoletniego pokrzywdzonego w sprawach o przestępstwa przeciwko wolności seksualnej i obyczajności — kilka uwag na tle nowelizacji wprowadzonej ustawą z dnia 13 czerwca 2013 r.
} o zmianie ustawy — Kodeks karny oraz ustawy - Kodeks postępowania karnego

\author{
JUSTYNA ŻYLIŃSKA
}

Uczelnia Techniczno-Handlowa im. Heleny Chodkowskiej

\section{Wprowadzenie}

Konsekwencje naruszenia takich dóbr jak wolność seksualna i obyczajność towarzyszą ofierze przez całe życie, w szczególności w sferze emocjonalnej i psychicznej. Ten rodzaj skrzywdzenia jest dla każdej osoby, a w szczególności dla dziecka, wysoce traumatyczny. Dlatego też unormowania procesowe regulujące uczestnictwo małoletniego w procesie karnym, zwłaszcza odnoszące się do jego udziału w czynnościach procesowych, takich jak na przykład przesłuchanie, powinny być ukształ- 
towane w taki sposób, by nie powodować zjawiska wiktymizacji wtórnej ze strony organów ścigania i wymiaru sprawiedliwości. Jak podkreśla J. Mierzwińska-Lorencka, regulacje te mają na celu zapobieganie traumatycznym przeżyciom dzieci uczestniczących w czynnościach procesowych przesłuchania, zwłaszcza podczas odtwarzania przebiegu przestępstw przeciwko wolności seksualnej i obyczajności. Celem tym jest także zminimalizowanie stresu wywołanego przesłuchaniem i odtwarzaniem przebiegu przestępstwa, a tym samym powracaniem do związanych z nim przeżyć, które mogą powodować zaburzenia funkcjonowania organizmu, w tym pamięci ${ }^{1}$.

Mając na celu dostosowanie prawa polskiego do standardów ochrony ofiary przestępstwa, zawartych w aktach prawa unijnego i międzynarodowego $^{2}$, ustawa z dnia 13 czerwca 2013 r. o zmianie ustawy - Kodeks karny oraz ustawy - Kodeks postępowania karnego ${ }^{3}$, która weszła w życie w dniu 27 stycznia 2014, wprowadza istotne zmiany do Kodeksu postępowania karnego ${ }^{4}$, w tym treści art. $185 \mathrm{a}$ k.p.k., normującego tryb przesłuchania małoletniego pokrzywdzonego, który w chwili przesłuchania nie ukończył 15 lat, w sprawach o przestępstwa w nim wymienione, m.in. przeciwko wolności seksualnej i obyczajności. Wspomniana nowelizacja nie tylko rozszerza zakres stosowania tego unormowania zarówno ze względu na sposób popełnienia przestępstwa, jak również na rodzaj czynu — ale także ogranicza możliwość przeprowadzenia prze-

${ }^{1}$ J. Mierzwińska-Lorencka, Karnoprawna ochrona dziecka przed wykorzystywaniem seksualnym, Warszawa 2012, s. 146.

${ }^{2}$ Ustawa z 13 czerwca 2013 r. dąży do dostosowania polskiego prawa do prawa Unii Europejskiej: Dyrektywy Parlamentu Europejskiego i Rady w sprawie zapobiegania handlowi ludźmi i zwalczania tego procederu oraz ochrony ofiar z dnia 5 kwietnia 2011 r. (Dz. Urz. UE L 335, 17 grudnia 2011 r., zwana „Dyrektywa 2011/36”), Dyrektywy Parlamentu Europejskiego i Rady w sprawie zwalczania niegodziwego traktowania w celach seksualnych i wykorzystywania seksualnego dzieci oraz pornografii dziecięcej z dnia 13 grudnia 2011 r. (Dz. Urz. UE L 101, 15 kwietnia 2011 r., zwana „Dyrektywa 2011/93") oraz Dyrektywy Parlamentu Europejskiego i Rady z dnia 25 października 2012 r. ustanawiającej normy minimalne w zakresie praw, wsparcia i ochrony ofiar przestępstw (Dz. Urz. UE L 315, 14 listopada 2012 r. zwana „Dyrektywa 2012/29”).

${ }^{3}$ Ustawa z dnia 13 czerwca 2013 r. o zmianie ustawy — Kodeks karny oraz ustawy — Kodeks postępowania karnego, Dz.U. z 2013 r., poz. 849.

${ }^{4}$ Ustawa z dnia 6 czerwca 1997 r., Kodeks postępowania karnego, Dz.U. Nr 89, poz. 555 ze zm. (w skrócie k.p.k.). 
słuchania pokrzywdzonego do sytuacji, gdy jego zeznania mogą mieć istotne znaczenie dla rozstrzygnięcia sprawy (art. 185a § 1 k.p.k.). Stwarza ona także możliwość objęcia trybem przesłuchania określonym w art. 185a k.p.k. w sprawach o przestępstwa w nim wymienione małoletniego pokrzywdzonego, który w chwili przesłuchania ukończył 15 lat, gdy jest to uzasadnione jego stanem psychicznym (art. 185a $\S 4$ k.p.k.). Kolejne istotne zmiany, które wprowadza ustawa z 13 czerwca 2013 r., to: nakaz wyznaczenia przez sąd obrońcy z urzędu, jeżeli oskarżony zawiadomiony o przesłuchaniu małoletniego pokrzywdzonego nie posiada obrońcy z wyboru (art. 185a § 2 zd. czwarte k.p.k.) oraz możliwość obecności przy przesłuchaniu osoby pełnoletniej wskazanej przez pokrzywdzonego (art. 185a $\S 2$ zd. trzecie k.p.k.). Nadto ustawa wprowadza zmiany do treści art. 185b k.p.k. dotyczącego przesłuchania świadka, który w chwili przesłuchania nie ukończył 15 lat, w sprawach o przestępstwa popełnione $\mathrm{z}$ użyciem przemocy lub groźby bezprawnej lub określone w rozdziałach XXV i XXVI Kodeksu karnego ${ }^{5}$. Dodaje także przepis $185 \mathrm{c}$ k.p.k. normujący zasady złożenia zawiadomienia przez pokrzywdzonego o przestępstwie oraz trybu jego przesłuchania, w sprawach o przestępstwa określone w art. 197-199 k.k., art. 185d k.p.k., określający wymogi co do miejsca, w którym powinno odbywać się przesłuchanie w trybie określonym $\mathrm{w}$ art. $185 \mathrm{a}-185 \mathrm{c}$ k.p.k. oraz przepis art. 147 k.p.k. § 2a, stanowiący, że przesłuchanie pokrzywdzonego, o którym mowa w art. 185 a i art. 185 c, oraz świadka, o którym mowa w art. 185b, utrwala się za pomocą urządzenia rejestrującego obraz i dźwięk.

$\mathrm{Z}$ uwagi na przedmiot opracowania koncentruje się ono na tych regulacjach, które odnoszą się do ochrony małoletniego pokrzywdzonego w sprawach o przestępstwa przeciwko wolności seksualnej i obyczajności.

\section{Zakres stosowania przepisu art. 185a k.p.k.}

Zasadniczym unormowaniem ustawy karno-procesowej, mającym na celu zapewnienie ochrony małoletniemu pokrzywdzonemu w sprawach o przestępstwa przeciwko wolności seksualnej i obyczajności, jest

${ }^{5}$ Ustawa z dnia 6 czerwca 1997 r. Kodeks karny, Dz.U. Nr 88, poz. 553 ze zm. (w skrócie k.k.). 
art. 185a k.p.k. o charakterze gwarancyjnym, zabezpieczającym interesy procesowe małoletniego pokrzywdzonego przesłuchiwanego $\mathrm{w}$ charakterze świadka. Regulacja ta $\mathrm{w}$ pierwotnym brzmieniu ograniczała możliwość zastosowania określonego w niej szczególnego trybu przesłuchania do wąskiego grona pokrzywdzonych — tych, których dobro prawne zostało bezpośrednio naruszone lub zagrożone przez przestępstwo określone w rozdziale XXV k.k. (przeciwko wolności seksualnej i obyczajności) i którzy w chwili czynu nie ukończyli 15 lat. Takie ujęcie spotkało się z krytyką — wskazywano, że zapewnia ono możliwość ochrony pokrzywdzonego w bardzo wąskim zakresie - tylko w odniesieniu do przestępstw przeciwko wolności seksualnej i obyczajności oraz że wiek pokrzywdzonego w chwili przesłuchania pozbawiony jest jakiegokolwiek znaczenia ${ }^{6}$. W konsekwencji w ustawie nowelizującej z dnia 3 czerwca 2005 r. słowa ,w chwili czynu” zastapiono słowami ,w chwili przesłuchania". Nadto zakresem analizowanego przepisu objęto także przestępstwa penalizowane w rozdziale XXVI — zatytułowanym Przestęstwa przeciwko rodzinie i opiece (art. 206-211 k.k.).

Zakres stosowania szczególnego trybu przesłuchania małoletniego pokrzywdzonego rozszerza również nowelizacja wprowadzona ustawą z dnia 13 czerwca 2013 r. o zmianie ustawy — Kodeks karny oraz ustawy - Kodeks postępowania karnego, obejmując nim nie tylko przestępstwa określone w rozdziale XXV k.k. i XXVI k.k., lecz również penalizowane w rozdziale XXIII k.k. zatytułowanym Przestepstwa przeciwko wol$n o s ́ c i^{7}$. Nadto zastosowanie trybu przesłuchania określonego w art. 185a $\S 1$ k.p.k. — po zmianach wprowadzonych przywołaną ustawą jest wska-

6 Zob. P. Świerk, Przestuchanie małoletniego pokrzywdzonego na podstawie art. 185 a Kodeksu postępowania karnego, „Prokuratura i Prawo” 2004, nr 5, s. 151; R. Stefański, Przestuchanie pokrzywdzonego ponizej lat $15 \mathrm{w}$ procesie karnym, [w:] Wspótczesne problemy procesu karnego i jego efektywność. Księga pamiatkowa Profesora Andrzeja Bulsiewicza, red. A. Marek, Toruń 2004, s. 377; A. Muszyńska, Karnoprocesowe i kryminalistyczne problemy przestuchania $w$ charakterze świadka osoby nieletniej, Acta UWr., „Przegląd Prawa i Administracji” 2005, nr 72, s. 179; D. Tarnowska, Przestuchanie pokrzywdzonego przestępstwem określonym $w$ rozdziale XXV, który w chwili czynu nie ukończyt 15 lat (art. 185 a k.p.k.), „Przegląd Sądowy” 2004, nr 10, s. 84.

7 Przestępstwa przeciwko wolności to: bezprawne pozbawienie wolności (art. 189 k.k.), handel ludźmi (art. 189a k.k.), groźba karalna (art. 190 k.k.), uporczywe nękanie (art. 190a k.k.), zmuszanie do określonego zachowania (art. 191 k.k.), utrwalanie wize- 
zane także w sprawach o przestępstwa popełnione z użyciem przemocy lub groźby bezprawnej. Jednocześnie przepis art. 185 a k.p.k. w $§ 1$ utrzymuje zasadę stosowania określonego w nim szczególnego trybu przesłuchania, w sprawach o przestępstwa w nim określone, w stosunku do pokrzywdzonego, który w chwili przesłuchania nie ukończył 15 lat.

W kontekście zakresu stosowania trybu przesłuchania określonego w art. 185a k.p.k. należy zwrócić uwagę, że art. 2 ust. 6 Dyrektywy Parlamentu Europejskiego i Rady 2011/36/UE z dnia 5 kwietnia 2011 r. w sprawie zapobiegania handlowi ludźmi i zwalczania tego procederu oraz ochrony ofiar, jak również art. 2 ust. 1 lit. c Dyrektywy Parlamentu Europejskiego i Rady z dnia 25 października 2012 r. ustanawiającej normy minimalne w zakresie praw, wsparcia i ochrony ofiar przestępstw, posługuje się pojęciem „dziecko”, definiowanym jako osoba poniżej 18. roku życia. Mając na uwadze konieczność dostosowania brzmienia art. 185a k.p.k. do standardów unijnych, ustawodawca dokonał rozszerzenia zakresu czynów, do których ma zastosowanie tryb przesłuchania określony w art. 185a k.p.k., oraz objął ochroną dzieci pokrzywdzone przestępstwem, które $\mathrm{w}$ chwili przesłuchania ukończyły 15 lat $-\S 4$ analizowanego unormowania przewiduje bowiem stosowanie $\S 1$ 1-3 art. 185 a k.p.k. do pokrzywdzonego, który w chwili przesłuchania ukończył 15 lat, pod warunkiem, że chodzi o przestępstwa wymienione w $\S 1$ art. 185 a k.p.k. oraz o sytuację, gdy zachodzi uzasadniona obawa, że przesłuchanie w innych warunkach mogłoby wywrzeć negatywny wpływ na jego stan psychiczny. W kontekście zagadnienia ochrony małoletniej ofiary przestępstwa, która w chwili przesłuchania ukończyła 15 lat, ustawodawca przyjmuje, iż zastosowanie szczególnego trybu odebrania oświadczenia dowodowego jest uzależnione od ustalenia, że przesłuchanie w innych warunkach mogłoby spowodować pogorszenie stanu zdrowia psychicznego osoby pokrzywdzonej przestępstwem. Oceny zaistnienia tej przesłanki dokonywałby organ procesowy na tle okoliczności konkretnej sprawy, przy czym zasadą powinno być uzyskanie opinii biegłego psychologa na tę okoliczność ${ }^{8}$.

runku nagiej osoby bez jej zgody (art. 191a k.k.), zabieg leczniczy bez zgody pacjenta (art. 192 k.k.), zakłócenie miru domowego (art. 193 k.k.).

8 Uzasadnienie projektu ustawy z dnia 13 czerwca 2013 r. o zmianie ustawy — Kodeks karny oraz ustawy — Kodeks postępowania karnego (druk 998), http://www.sejm. 


\section{Zasada jednorazowości przesłuchania małoletniego pokrzywdzonego w sprawach o przestępstwa przeciwko wolności seksualnej i obyczajności}

Przepis art. 185a k.p.k., mając na uwadze ochronę małoletniego pokrzywdzonego, proklamuje obecnie zasadę, że jego przesłuchanie w charakterze świadka przeprowadza się tylko wówczas, gdy jego zeznania mogą mieć istotne znaczenie dla rozstrzygnięcia sprawy. Tak na przykład będzie w sytuacji, gdy świadek, ze względu na wiek, nie miał możliwości spostrzeżenia, zapamiętania lub odtworzenia okoliczności istotnych w sprawie, a dotyczących przestępnego zachowania sprawcy. Ogólnie można powiedzieć, że dotyczy to każdej okoliczności dotyczącej świadka, jego cech i właściwości psychicznych, czy też sytuacji, w jakiej doszło do pokrzywdzenia, jak i w okresie wcześniejszym, które wykluczają możliwość przekazania przez świadka faktów istotnych dla rozstrzygnięcia sprawy ${ }^{9}$. Tym samym ustawodawca dopuszcza możliwość nieprzesłuchiwania małoletniego pokrzywdzonego w ogóle w toku całego postępowania karnego, jeżeli jego zeznania nie wpływałyby na treść rozstrzygnięcia. Ocena takiej sytuacji każdorazowo będzie należała do organu procesowego i zależała od zgromadzonego materiału dowodowego ${ }^{10}$.

Jednocześnie ustawa nowelizująca z 13 czerwca 2013 r. utrzymuje zasade jednokrotnego przesłuchania pokrzywdzonego, tym samym ustawodawca daje wyraz dążeniu do zapewnienia ochrony dziecku pokrzywdzonemu przestępstwem przed wielokrotnym stawianiem go w sytuacji stresowej, niejednokrotnie krępującej, wywołującej poczucie wstydu, negatywne uczucia, takie jak pogarda, gniew, nienawiść, żal wobec sprawcy, a także - co gorsza, wobec samego siebie ${ }^{11}$.

gov.pl/sejm7.nsf/druk.xsp?nr=998_(dostęp: 31.12.2014), s. 17-18.

9 L.K. Paprzycki (red.), J. Grajewski, S. Steinborn, Komentarz aktualizowany do art. 1-424 ustawy z dnia 6 czerwca 1997 r., Kodeks postepowania karnego (Dz.U. 97.89.555), Lex/el 2014, teza 1b do art. 185a k.p.k._(dostęp: 31.12.2014).

10 A.Z. Krawiec, Przestuchanie matoletniego świadka po nowelizacji Kodeksu postepowania karnego, „Prokuratura i Prawo” 2013, nr 12, s. 120.

11 J. Mierzwińska-Lorencka, op. cit., s. 195. 
Mając na uwadze powyższe okoliczności, ustawa karno-procesowa wyjątkowo dopuszcza odstępstwa od zakazu ponownego przesłuchania małoletniego pokrzywdzonego, przewidując dwie sytuacje tego rodzaju:

— wyjście na jaw istotnych okoliczności, których wyjaśnienie wymaga ponownego przesłuchania,

— zgłoszenie przez oskarżonego żądania ponownego przesłuchania, co może mieć miejsce wtedy, gdy nie miał on obrońcy w czasie pierwszego przesłuchania pokrzywdzonego ${ }^{12}$.

W kontekście pierwszej z wymienionych powyższej sytuacji warunkującej ponowne przesłuchanie małoletniego pokrzywdzonego należy przede wszystkim podkreślić, iż sędzia, przystępując do przesłuchania małoletniego pokrzywdzonego, powinien dysponować materiałem dowodowym, który umożliwi mu pełne rozpytanie dziecka, co z pewnością będzie stanowić gwarancję uniknięcia ponownego przesłuchania dziecka $\mathrm{w}$ związku z nowo odkrytymi istotnymi okolicznościami ${ }^{13}$. Oczywiście w praktyce mogą pojawić się okoliczności uzasadniające konieczność ponownego przesłuchania. W doktrynie podkreśla się, iż winny to być okoliczności nieznane wcześniej organowi procesowemu, wynikające $\mathrm{z}$ dalszych czynności dowodowych przeprowadzonych w sprawie, $\mathrm{w}$ tym również z przesłuchania oskarżonego, czy też takie, których ujawnienie związane jest $\mathrm{z}$ dokonana przez organ procesowy oceną przeprowadzonych dowodów, np. pojawiające się w sytuacji oceny zeznań małoletniego świadka w momencie odczytania protokołu przeprowadzonej czynności ${ }^{14}$.

Ponadto winny to być okoliczności mające istotne znaczenie dla rozstrzygnięcia sprawy ${ }^{15}$. Zakres treściowy pojęcia „okoliczności istotne” nie został przez ustawodawcę określony. Jako wyrażenie o charakterze ocennym oraz nieostrym zakresie jest trudne do zdefiniowania. Ponadto cechuje je daleko idąca relatywizacja. To, co bowiem jest istotną okolicznością

12 Zob. P. Hofmański, D. Szumiało-Kulczycka, Prawo do obrony a ochrona pokrzywdzonego przestępstwem - uwagi na tle art. 185 a i standardów Europejskiej Konwencji Praw Człowieka, [w:] $W$ kręgu prawa nieletnich. Ksiega pamiatkowa ku czci Profesor Marianny Korcyl-Wolskiej, red. P. Hofmański, S. Waltoś, Warszawa 2009, s. 305-319.

${ }^{13}$ M. Kornak, Małoletni jako świadek w procesie karnym, Warszawa 2009, s. 159.

14 J. Mierzwińska-Lorencka, op. cit., s. 195.

15 A. Wesołowska, Regulacje prawne dotyczqce ochrony małoletnich $w$ toku postępowania karnego, „Dziecko krzywdzone” 2007, nr 3 (20), s. 39. 
w jednej sprawie, niekoniecznie musi okazać się taką w innej. Ocena charakteru okoliczności na etapie podejmowania decyzji o powtórnym przesłuchaniu przez sąd jest niejako sformułowaniem prognozy. Niekiedy więc jej dokonanie może stwarzać sądowi trudności, trudno bowiem czasami niejako „z góry” ocenić walor danej okoliczności jako istotnej. Dlatego też jeżeli istnieje możliwość ustalenia danej okoliczności istotnej w oparciu o inne dowody, zalecić należy skorzystanie w pierwszej kolejności z tej możliwości. Dopiero wówczas, gdy to rozwiązanie okaże się nieefektywne, wskazane jest ponowne przesłuchanie małoletniego pokrzywdzonego w trybie art. 185 a $§ 1$ k.p.k. odnośnie do tychże okoliczności.

Ponowne przesłuchanie małoletniego w sytuacji zaistnienia analizowanej przesłanki może nastąpić nie tylko z urzędu, ale również zostać zainicjowane w wyniku uwzględnienia wniosku dowodowego złożonego przez stronę postępowania. Wniosek o powtórzenie czynności przesłuchania pokrzywdzonego z uwagi na ujawnienie się nowych istotnych okoliczności może złożyć zarówno sam oskarżony, jak i jego obrońca. Powtórnego przesłuchania, z uwagi na analizowaną przesłankę, zażądać może także sam pokrzywdzony, czy też jego przedstawiciel ustawowy, ewentualnie osoba, pod której stałą pieczą pozostaje małoletni, co jest uzasadnione tym, że pokrzywdzony, składając zeznanie o traumatycznych dla siebie przeżyciach, może w swojej wypowiedzi po prostu pominąć informacje o pewnych istotnych dla sprawy faktach i przypomnieć je sobie dopiero po zakończeniu czynności ${ }^{16}$.

Istotną kwestią — z punktu widzenia realizacji zasady jednokrotnego przesłuchania pokrzywdzonego — jest posiadanie obrońcy przez oskarżonego w czasie przesłuchania przeprowadzanego w trybie art. 185a k.p.k., co prowadzi do ograniczenia sytuacji, w których konieczne jest ponowne przesłuchanie małoletniego pokrzywdzonego z powodu nieposiadania obrońcy przez oskarżonego w czasie pierwszego przesłuchania małoletniego. Mając na względzie powyższe założenie, pozytywnie należy ocenić zmianę brzmienia art. 185a § 2 k.p.k., wprowadzoną ustawą z dnia 13 czerwca 2013 r. - zdanie czwarte tegoż przepisu wprowadza wymóg, iż podejrzany musi być reprezentowany przez obrońcę w cza-

16 Zob. M. Klejnowska, Przestuchanie nieletniego w postępowaniu karnym a europejskie standardy ochrony praw czlowieka, [w:] Europejskie standardy ochrony praw czlowieka a ustawodawstwo polskie, red. E. Dynia, C.P. Kłak, Rzeszów 2005, s. 318. 
sie przesłuchania przeprowadzanego w tym trybie, stanowiąc że, jeżeli oskarżony zawiadomiony o przesłuchaniu nie posiada obrońcy z wyboru, sąd wyznaczać mu będzie obrońcę z urzędu. Celem ustawodawcy - co wynika z uzasadnienia projektu ustawy z dnia 13 czerwca 2013 r. — było: z jednej strony — o czym była mowa powyżej — zmniejszenie liczby ponawianych przesłuchań dzieci z uwagi na nieposiadanie obrońcy przez oskarżonego w czasie pierwszego przesłuchania. Z drugiej strony unormowanie to gwarantuje oskarżonemu prawo do rzetelnego procesu, zgodnie z wymogami art. 6 ust. 3 lit. d Konwencji o ochronie praw człowieka i podstawowych wolności ${ }^{17}$. Z orzecznictwa Trybunału wynika, że w przypadku pokrzywdzonych dzieci dopuszczalne są pewne odstępstwa od zapewnienia oskarżonym prawa do zadawania im pytań bezpośrednio na rozprawie. Za akceptowalny standard uznaje się umożliwienie zadawania pytań pokrzywdzonemu na którymkolwiek etapie postępowania i za pośrednictwem obrońcy. Do naruszenia art. 6 Konwencji nie dochodzi nawet wówczas, gdy obrońca oskarżonego, prawidłowo zawiadomiony o tej czynności, zrezygnował z udziału w przesłuchaniu dziecka, a następnie nagranie tej czynności odtworzono na rozprawie. Oczywiście zmiany proponowane w art. 185a $§ 2$ k.p.k. nie wyeliminują możliwości wnioskowania o kolejne przesłuchanie małoletniego, gdy pierwsze odbyło się przed przeprowadzeniem czynności przedstawienia zarzutów podejrzanemu. Powinny jednak ograniczyć liczbę przypadków, w których do ponownego przesłuchania małoletniego dochodzi nie z powodu ujawnienia się nowych istotnych okoliczności, których wyjaśnienie wymaga ponownego przeprowadzenia tej czynności, a jedynie z powodu nieposiadania obrońcy przez podejrzanego w czasie pierwszego przesłuchania małoletniego ${ }^{18}$.

Na kanwie omawianej problematyki warto zauważyć, iż w uprzednio obowiązującym stanie prawnym — z uwagi na fakt, iż art. 185a k.p.k. nie przewidywał możliwości wyznaczenia obrońcy z urzędu - tak jak to czyni obecnie, w literaturze przedmiotu - mając na celu ograniczenie ilości przesłuchań małoletniego pokrzywdzonego, proponowano rozwiązanie polegające na przyznaniu oskarżonemu obrońcy z urzędu w sytu-

17 Konwencja o ochronie praw człowieka i podstawowych wolności, sporządzona w Rzymie 4 listopada $1950 \mathrm{r}$.

18 Uzasadnienie projektu ustawy..., s. 17. 
acji przystąpienia do przesłuchania w trybie art. 185a k.p.k., wywodząc taką możliwość z przepisu art. 79 § 2 k.p.k. stanowiącego, że oskarżony musi mieć obrońcę, gdy sąd uzna to za niezbędne ze względu na okoliczności utrudniające obronę ${ }^{19}$. Pogląd ten nie był jednakże przyjmowany bez zastrzeżeń.

\section{Organ uprawniony do przesłuchania małoletniego} pokrzywdzonego w sprawach o przestępstwa przeciwko wolności seksualnej i obyczajności w trybie art. 185 a k.p.k. oraz podmioty uczestniczące $\mathrm{w}$ tym przesłuchaniu

Czynność przesłuchania małoletniego pokrzywdzonego w sprawach o przestępstwa przeciwko wolności seksualnej i obyczajności, niezależnie od tego, w jakiej fazie postępowania jest dokonywana, jest przeprowadzana przez sąd na posiedzeniu. W przepisie art. 185 a k.p.k. zostały wskazane także inne osoby - obok sądu, który przeprowadza przesłuchanie i biegłego - mogące uczestniczyć w tej czynności. W konsekwencji prawo wzięcia udziału w przesłuchaniu mają prokurator, obrońca oraz pełnomocnik pokrzywdzonego. Osoba wymieniona w art. $51 \S 2$ (przedstawiciel ustawowy albo osoba, pod której pieczą pokrzywdzony pozostaje) lub - co stanowi novum - osoba pełnoletnia wskazana przez pokrzywdzonego ma prawo również być obecna przy przesłuchaniu, jeżeli nie ogranicza to swobody wypowiedzi przesłuchiwanego.

Art. 185a § 2 k.p.k. stanowi samodzielną podstawę dla udziału psychologa $\mathrm{w}$ przesłuchaniach dzieci $\mathrm{w}$ trybie szczególnym. Wskazany przepis stanowi lex specialis w stosunku do art. 192 § 2 k.p.k. Biegły zatem powoływany jest niezależnie od tego, czy zaistniały wątpliwości co do stanu psychicznego świadka, stanu rozwoju umysłowego, zdolności spostrzegania, czy też możliwości odtwarzania (są to okoliczno-

19 Zob. M. Kornak, op. cit., s. 159; R. Kosior, Wybrane zagadnienia w zakresie przestuchania małoletniego świadka na tle art. 185 a i 185 b k.p.k., ,Dziecko krzywdzone" 2010, nr 1 (30), s. 21; V. Kwiatkowska-Darul, Przestuchanie małoletniego świadka w polskim procesie karnym, Toruń 2007, s. 172; J. Mierzwińska-Lorencka, op. cit., s. 198; A. Wesołowska, Regulacje prawne dotyczace ochrony małoletnich $w$ toku postępowania karnego, „Dziecko krzywdzone” 2007, nr 3 (20), s. 41. 
ści, które upoważniają sąd lub prokuratora do zarządzenia przesłuchania w trybie przepisu art. $192 \S 2$ k.p.k. ${ }^{20}$. Jak wspomniano powyżej, prawo do udziału w przesłuchaniu przeprowadzonym w trybie art. 185 a k.p.k. mają także prokurator, obrońca, pełnomocnik pokrzywdzonego oraz osoba, o której mowa w art. $51 \S 2$ k.p.k. lub osoba pełnoletnia wskazana przez pokrzywdzonego.

Analizowane unormowanie, co zresztą zrozumiałe, nie przewiduje natomiast udziału oskarżonego (podejrzanego) w przesłuchaniu, gdyż jego obecność mogłaby wpływać deprymująco na świadka. Jak trafnie podkreślają P. Hofmański, E. Sadzik, K. Zgryzek, wyjątkowość sytuacji i potrzeba ochrony istotnego interesu pokrzywdzonego usprawiedliwia regulację, w świetle której oskarżony w ogóle może nie mieć okazji do zadania pytań pokrzywdzonemu ${ }^{21}$.

Podmiotem, któremu zostały przyznane uprawnienia w zakresie możliwości uczestniczenia w przesłuchaniu, jest osoba, do której odnosi się bezpośrednio regulacja zawarta w art. $51 \S 2$ k.p.k. Przepis, do którego art. 185a k.p.k. w tym zakresie odsyła, stanowi, że za pokrzywdzonego, który jest małoletni albo ubezwłasnowolniony całkowicie lub częściowo, prawa wykonuje jego przedstawiciel ustawowy albo osoba, pod której pieczą pokrzywdzony pozostaje. Redakcja przepisu 185a § 2 k.p.k. nie jest jednak bezwarunkowa. Osoba, o której mowa powyżej, może być obecna podczas takiego przesłuchania, o ile nie ogranicza swoją obecnością swobody wypowiedzi przesłuchiwanego dziecka. Oceny, czy taka sytuacja może zachodzić w danej sprawie, dokonuje sąd ${ }^{22}$.

Istotną zmiana, jaką w katalogu podmiotów biorących udział w przesłuchaniu małoletniego, przeprowadzanego w trybie art. 185 a k.p.k., wprowadziła ustawa nowelizująca z dnia 13 czerwca 2013 r., jest dopuszczenie do udziału w przesłuchaniu osoby pełnoletniej wskazanej przez pokrzywdzonego (np. nauczyciela, sąsiadki). Ma ona prawo być obecna przy przesłuchaniu, jeżeli nie ogranicza to swobody wypowiedzi przesłuchiwanego. Oceny zaistnienia tej przesłanki dokonuje organ procesowy

20 R.A. Stefański, Szczególne tryby przestuchania $w$ postępowaniu karnym świadka małoletniego, który nie ukończyt 15 lat, ,Wojskowy Przegląd Prawniczy” 2005, nr 4, s. 94.

21 Ibidem, s. 877.

22 K. Chmielewska, Ochrona przestuchiwanych dzieci, Warszawa 2013, s. 41. 
na tle okoliczności konkretnej sprawy, przy czym zasada powinno być uzyskanie opinii biegłego psychologa na tę okoliczność ${ }^{23}$. Rozwiązanie to czyni zadość art. 20 ust. 3 lit. f dyrektywy 2011/93/UE stanowiącej, iż bez uszczerbku dla prawa do obrony państwa członkowskie podejmują środki niezbędne do zapewnienia, by w ramach postępowań karnych dotyczących przestępstw, o których mowa w art. 3-7 dyrektywy, pokrzywdzonemu dziecku mógł towarzyszyć jego przedstawiciel prawny lub, w odpowiednich przypadkach, wybrana przez nie osoba dorosła, o ile nie podjęto odmiennej umotywowanej decyzji w odniesieniu do tej osoby. Analogiczne rozwiązanie przyjmuje art. 15 ust. 3 lit. f dyrektywy 2011/36/UE.

W kontekście omawianego zagadnienia celowe jest zwrócenie uwagi, że ustawodawca, wskazując w przepisie art. 185a $\S 2$ zd. 3 k.p.k. na prawo do obecności osoby wymienionej w art. $51 \S 2$ k.p.k. oraz osoby pełnoletniej wskazanej przez pokrzywdzonego, używa spójnika „lub”, co w rezultacie nie wyklucza jednoczesnego uczestnictwa obu rodzajów podmiotów. Jedyną przesłanką wyłączającą udział takiego podmiotu będzie chociażby minimalne zagrożenie braku swobody w składaniu zeznań przez pokrzywdzonego. Taka sytuacja może zaistnieć nie tylko ze względu na rodzaj i okoliczności popełnionego na szkodę małoletniego przestępstwa, ale także wtedy, gdy którakolwiek z uczestniczących w przesłuchaniu osób byłaby sprawcą albo pozostawałaby w bliskiej relacji ze sprawcą takiego przestępstwa ${ }^{24}$. Natomiast decyzja o wyborze osoby uczestniczącej w przesłuchaniu — jak słusznie zauważa D. Karmarska - pozostaje w gestii małoletniego pokrzywdzonego, składającego w tym zakresie samodzielne oświadczenie woli, którego skuteczność nie zależy od stanowiska osoby wymienionej w art. $51 \S 2$ k.p.k. Osoba wskazana przez małoletniego może zatem uczestniczyć w przesłuchaniu mimo braku zgody przedstawiciela ustawowego, a nawet przy jego sprzeciwie. Jedynie ocena sądu w kwestii negatywnego wpływu tej osoby na swobodę wypowiedzi przesłuchiwanego spowoduje niedopuszczenie jej do udziału w przesłuchaniu ${ }^{25}$.

23 Zob. Uzasadnienie..., s. 17-18.

24 A.Z. Krawiec, op. cit., s. 124.

25 D. Karmarska, Przesłuchanie małoletniego pokrzywdzonego w świetle nowelizacji Kodeksu postępowania karnego, „Prokuratura i Prawo” 2014, nr 1, s. 27. 
V. Taktyka przesłuchania małoletniego pokrzywdzonego w świetle rozporządzenia Ministra Sprawiedliwości z dnia 18 grudnia 2013 r. w sprawie sposobu przygotowania przesłuchania przeprowadzanego $\mathrm{w}$ trybie określonym w art. 185a-185c Kodeksu postępowania karnego

Ustawodawca, dążąc do sprostania standardom unijnym oraz postulatom formułowanym przez psychologów oraz procesualistów ${ }^{26}$, expressis verbis określił wymogi co do miejsca, w którym powinno odbywać się przesłuchanie pokrzywdzonego dziecka w sprawach o przestępstwa przeciwko wolności seksualnej i obyczajności. Normujący tę kwestię art. 185d k.p.k. - dodany ustawą nowelizującą z 13 czerwca 2013 r. - w paragrafie pierwszym stanowi, iż przesłuchanie w trybie określonym $\mathrm{w}$ art. 185a-185c przeprowadza się $\mathrm{w}$ odpowiednio przystosowanych pomieszczeniach w siedzibie sądu lub poza jego siedziba, a jednocześnie w paragrafie drugim formułuje delegację dla Ministra Sprawiedliwości, by w drodze rozporządzenia określił sposób przygotowania tego przesłuchania oraz warunki, jakim powinny odpowiadać pomieszczenia przeznaczone do przeprowadzania takich przesłuchań, w tym ich wyposażenie techniczne, mając na względzie konieczność zapewnienia swobody wypowiedzi i poczucia bezpieczeństwa osób przesłuchiwanych ${ }^{27}$. W konsekwencji szczegółowe warunki, jakim powinny odpowiadać pomieszczenia przeznaczone do przeprowadzania przesłuchania, określa rozporządzenie Ministra Sprawiedliwości z dnia 18 grudnia 2013 r. w sprawie sposobu przygotowania przesłuchania przeprowadzanego w trybie określonym w art. 185a-185c Kodeksu po-

${ }^{26}$ Zob. R. Górecki, Świadek w postępowaniu przygotowawczym, Warszawa-Poznań 1987, s. 94; K. Krasny, Swoboda wypowiedzi osoby przestuchiwanej, „Prokuratura i Prawo" 1996, nr 10, s. 45-62; J. Mierzwińska-Lorencka, op. cit., s. 322.

27 Rozwiazzanie to jest zgodne z art. 23 ust. 2 lit. a dyrektywy 2012/29/UE, określonym zgodnie z art. 22 ust. $1 \mathrm{w}$ myśl którego przesłuchania ofiar o szczególnych potrzebach w zakresie ochrony odbywają się w zaprojektowanych lub przystosowanych do tego celu pomieszczeniach. Nadto odnotować należy jego zgodność z art. 20 ust 3 lit. b dyrektywy 2011/93/UE oraz z 15 ust 3 lit. b dyrektywy 2011/36/UE. 
stępowania karnego ${ }^{28}$. W myśl unormowań zawartych w przywołanym rozporządzeniu na potrzeby prowadzenia przesłuchania wyodrębnia się pokój przesłuchań i pokój techniczny ( $\$ 5$ ust. 1 rozporządzenia). Pokój przesłuchań służy do przeprowadzenia przesłuchania świadka przez sędziego w obecności i z udziałem biegłego psychologa oraz tłumacza, jeżeli został powołany ( $§ 5$ ust. 2 rozporządzenia).

Pokój przesłuchań może znajdować się w siedzibie sądu, prokuratury, policji, instytucji państwowej lub samorządowej albo podmiotu, do którego zadań należy pomoc małoletnim lub ofiarom przestępstwa zgwałcenia. W przypadku gdy żaden podmiot wskazany powyżej nie posiada na obszarze właściwości sądu pokoju przesłuchań spełniającego warunki określone w rozporządzeniu lub pokój taki nie jest dostępny, przesłuchanie można przeprowadzić w pokoju przesłuchań spełniającym te warunki udostępnionym przez inny podmiot ( $\$ 6$ rozporządzenia).

Jeżeli warunki lokalowe to umożliwiają, pokój przesłuchań znajdujący się w budynku sądu, prokuratury lub Policji powinien posiadać odrębne wejście lub być zlokalizowany w taki sposób, aby dojście do niego nie prowadziło przez części budynku, gdzie przebywają oskarżeni, zatrzymani lub pokrzywdzeni innymi czynami, w bezpośrednim sąsiedztwie pokoju przesłuchań powinien znajdować się ustęp, możliwie najbliżej pokoju przesłuchań należy wyodrębnić poczekalnię ( $\$ 7$ rozporządzenia).

Pomieszczenie to powinno być nie tylko izolowane od odgłosów dobiegających z zewnątrz, czy odpowiednio urządzone (jasna, stonowana kolorystyka, meble zarówno dla osób dorosłych jak i dzieci), ale również wyposażone w środki techniczne umożliwiające:

- utrwalanie obrazu i dźwięku z przebiegu przesłuchania,

- obserwowanie i słuchanie przebiegu przesłuchania przez uczestników czynności przebywających w pokoju technicznym,

- przekazywanie sędziemu prowadzącemu przesłuchanie oraz biegłemu psychologowi pytań do świadka oraz wypowiedzi kierowanych przez uczestników czynności przebywających w pokoju technicznym,

28 Rozporządzenie Ministra Sprawiedliwości z dnia 18 grudnia 2013 r. w sprawie sposobu przygotowania przesłuchania przeprowadzanego w trybie określonym w art. 185a-185c Kodeksu postępowania karnego, Dz.U., poz. 1642. 
- utrwalanie, w formie zapisu dźwięku, pytań do świadka oraz wypowiedzi kierowanych przez uczestników czynności przebywających w pokoju technicznym ( $\$ 8$ i 9 rozporządzenia).

Natomiast pokój techniczny jest to pomieszczenie przylegające do pokoju przesłuchań i oddzielone od niego lustrem obserwacyjnym, albo pomieszczenie połączone z pokojem przesłuchań za pomocą środków technicznych umożliwiających przeprowadzenie przesłuchania na odległość z jednoczesnym bezpośrednim przekazem obrazu i dźwięku; w takim wypadku pokój techniczny może znajdować się w innym budynku niż pokój przesłuchań ( $§ 5$ ust. 3 rozporządzenia).

Pokój techniczny umożliwia uczestniczenie w przesłuchaniu prokuratorowi, obrońcy i pełnomocnikowi pokrzywdzonego; w pokoju tym przebywa również protokolant. Za zgodą sędziego w pokoju przesłuchań może przebywać podczas przesłuchania osoba, o której mowa w art. 51 $\S 2$ k.p.k. - przedstawiciel ustawowy lub osoba, pod której stałą pieczą pokrzywdzony pozostaje, albo osoba pełnoletnia wskazana przez pokrzywdzonego, o której mowa w art. 185 a $§ 2$ k.p.k.

W kontekście rozważań dotyczących miejsca przesłuchania małoletniego w sprawach o przestępstwa przeciwko wolności seksualnej i obyczajności podkreślić należy, że przed wejściem w życie analizowanej nowelizacji brak obligatoryjności do przesłuchania w ,przyjaznym pokoju przesłuchań" powodował, iż w praktyce karno-procesowej niestety reguły nie stanowiło przesłuchanie w specjalnie przystosowanym do tego celu pomieszczeniu. Wskazują na to chociażby wyniki badań 111 spraw karnych prawomocnie zakończonych, przeprowadzone w 2010 roku przez O. Trochę $^{29}$. W objętych badaniem sprawach prokuratorskich prowadzonych w trybie art. 185 a k.p.k. w pierwszym przesłuchaniu w sprawie przesłuchiwano głównie na sali sądowej (40\% przesłuchań), zaś w 20\% przypadków — w pokoju prokuratora. Tylko $11,1 \%$ przesłuchań odbyło się w przyjaznym pokoju, zaś 4,4\% w innych miejscach. W wypadku $24,4 \%$ przesłuchań protokoły nie zawierały informacji, gdzie przesłuchanie się odbyło, wobec czego przyjęto domniemanie, iż brak wskazania konkretnego miejsca w przypadku trybu art. 185a k.p.k. oznacza, że przesłucha-

29 Badania zostały przeprowadzone $\mathrm{w}$ ramach projektu realizowanego przy wsparciu Komisji Europejskiej - Dyrekcji Generalnej ds. Sprawiedliwości, Wolności i Bezpieczeństwa w ramach programu Prevention of and Fight against Crime. 
nie odbyło się na sali sądowej, gdyż tam właśnie odbywają się posiedzenia sądu. Natomiast jeżeli chodzi o sprawy sądowe, to pierwsze przesłuchanie małoletniego pokrzywdzonego w trybie art. 185a k.p.k. w zdecydowanej większości odbywało się na sali sądowej (51,1\%), 29,8\% przesłuchań odbyło się w przyjaznym pokoju, $14,9 \%$ przesłuchań przeprowadzono w pokoju sędziowskim, 2,1\% na komisariacie policji, 2,1\% w sali szpitalnej ${ }^{30}$.

Podobne wnioski wynikają również z badań aktowych przeprowadzonych przez J. Mierzwińską-Lorencką, która analizie poddała 107 prawomocnie zakończonych postępowań w sprawach kwalifikowanych $\mathrm{z}$ art. 200 oraz 201 k.k., w których przesłuchano w trybie art. 185a k.p.k. 142 dzieci, a przesłuchanie nastapiło po 29 sierpnia $2005 \mathrm{r}^{31}$

Powyższe dane zaskakują, tym bardziej, że w myśl przepisu art. 43 $\S 1$ ustawy z dnia 27 lipca 2001 r. — Prawo o ustroju sądów powszechnych ${ }^{32}$ — sąd mógł i może pełnić czynności poza swoją siedzibą, a w razie konieczności także poza obszarem swojej właściwości, jeżeli wymaga tego dobro wymiaru sprawiedliwości lub jeżeli przez to nastapi znaczne zmniejszenie kosztów. Jednakże sądy - co wynika z prezentowanych powyżej danych — rzadko korzystają z tej możliwości, a niestety nadal w wielu polskich sądach nie ma zapewnionych warunków do przesłuchiwania małoletnich poniżej 15. roku życia. Sprawia to, iż dominuje rozwiązanie polegające na przeprowadzaniu przesłuchań realizowanych w trybie art. 185a k.p.k. nie w przyjaznych pokojach przesłuchań, lecz na zwykłej sali rozpraw ${ }^{33}$.

Mając na uwadze powyższe, pozytywnie ocenić należy zmianę wprowadzoną ustawą nowelizującą z 13 czerwca 2013 r. wskazującą wymogi co do miejsca, w którym powinno odbywać się przesłuchanie dziecka. Niewątpliwie zrealizowanie tych wymogów stworzy podstawę do odebrania od małoletniego oświadczenia dowodowego w warunkach stwarzających

30 O. Trocha, Praktyka przestuchiwania dzieci w Polsce. Raport z badań aktowych, [w:] Dzieci uczestniczqce w procedurach karnych i cywilnych, "Dziecko krzywdzone. Teoria, badania, praktyka" 2011, nr 2 (35), s. 44-45.

31 Zob. J. Mierzwińska-Lorencka, op. cit., s. 320-322.

32 Ustawa z dnia 27 lipca 2001 r. - Prawo o ustroju sądów powszechnych, t.j. Dz.U. z 2013 r., poz. 427 ze zm.

33 Zob. M. Keller-Hamela, Standardy wyposażenia i korzystania z przyjaznych pokoi przestuchań dzieci, [w:] eadem, Przyjazne przestuchanie dziecka, Warszawa 2007, s. 83; A.Z. Krawiec, op. cit., s. 121-122. 
mu poczucie bezpieczeństwa i komfortu psychicznego, sprzyjających nawiązaniu kontaktu z osobami prowadzącymi czynność, w tym mobilizowaniu pamięci i otwartości wypowiedzi oraz koncentrowaniu uwagi ${ }^{34}$.

Rozporządzenie Ministra Sprawiedliwości z dnia 18 grudnia 2013 r. określa nie tylko warunki, jakim powinny odpowiadać pomieszczenia przeznaczone do przeprowadzenia przesłuchania, ale podejmuje również kwestię sposobu przygotowania przesłuchania przeprowadzanego $\mathrm{w}$ trybie określonym w art. 185a-185c k.p.k. Jest to zagadnienie niezwykle istotne, gdyż właściwe przygotowanie dziecka do wystąpienia w sądzie, świadomość jego potrzeb rozwojowych oraz współpraca interdyscyplinarna okazują się w wielu wypadkach wystarczające do złagodzenia stresu związanego z uczestnictwem w postępowaniu sądowym i do zwiększenia zdolności świadka do składania wiarygodnych zeznan ${ }^{35}$. Doniosłe znaczenie w czynnościach związanych z przesłuchaniem małoletniego w sprawach przeciwko wolności seksualnej i obyczajności odgrywa biegły psycholog. Jego pomoc jest nieoceniona, jeżeli chodzi o przygotowanie małoletniego pokrzywdzonego do przesłuchania czy ustalenie właściwej taktyki przesłuchania - co zresztą dostrzega normodawca. Paragraf czwarty przywołanego rozporządzenia formułuje bowiem zalecenie, by przed rozpoczęciem przesłuchania biegły psycholog przeprowadził ze świadkiem wstępną rozmowę w celu obniżenia poziomu lęku i niepokoju świadka. Natomiast jeżeli świadek jest małoletnim, który w chwili przesłuchania nie ukończył 15 lat, lub osobą cierpiącą na upośledzenie umysłowe, biegły psycholog w miarę potrzeby udziela sędziemu pomocy w wyjaśnieniu w sposób zrozumiały dla świadka zasad przesłuchania, w tym prawa odmowy składania zeznań, o ile prawo to świadkowi przysługuje, obowiązku mówienia prawdy i faktu utrwalania czynności w formie zapisu na nośnikach. Rozporządzenie wskazuje także na możliwość uzgodnienia z biegłym psychologiem sposobu formułowania zadawanych świadkowi pytań. Przed rozpoczęciem przesłuchania małoletniego, który w chwili

34 J. Mierzwińska-Lorencka, op. cit., s. 317.

35 K.J. Saywitz, G.S. Goodman, Interviewing children in and out of court: Current research and practice implications, [w:] The APSAC handbook on child maltreatment, red. J. Briere, et al., Sage, Thousand Oaks CA 2006, s. 297-318, za: J. Lipovsky, P. Stern, Przygotowanie dziecka do roli $w$ sqdzie — podejście interdyscyplinarne, www.dzieckoswaidek.pl (dostęp: 31.12.2014). 
przesłuchania nie ukończył 15 lat, lub osoby cierpiącej na upośledzenie umysłowe, a także w innych wypadkach uzasadnionych stanem emocjonalnym lub właściwościami osobistymi świadka, sędzia, prokurator, obrońca i pełnomocnik pokrzywdzonego mogą bowiem uzgodnić z biegłym psychologiem sposób formułowania zadawanych świadkowi pytań, w szczególności dotyczących sfery intymnej (§ 3 ust. 1 rozporządzenia).

Kolejną istotną kwestią związaną z przygotowaniem przesłuchania, do której odnosi się rozporządzenie Ministra Sprawiedliwości z dnia 18 grudnia 2013 r. jest pora i czas przesłuchania. Zagadnienie to, aczkolwiek często podejmowane w literaturze kryminalistyczno-procesowej, jako czynnik warunkujący efektywność przesłuchania małoletniego, w praktyce jest pomijane, a wybór terminu przesłuchania podyktowany jest względami technicznymi i organizacyjnymi - odbywa się ono w dniu i godzinie dogodnej dla sędziego przeprowadzającego czynność czy wówczas gdy dostępny jest sprzęt do utrwalenia dźwięku i obrazu. A przecież — na co zwraca uwagę J. Mierzwińska-Lorencka - wyznaczenie godziny przesłuchania w czasie „dogodnym” dla małoletniego niewątpliwie wpływa na podwyższenie gotowości do współpracy i zarazem nie obniża jego motywacji do składania zeznań. Zależność tę wydaje się również dostrzegać normodawca, gdyż w $§ 2$ rozporządzenia, wprowadza zasadę, że jeżeli świadek jest małoletnim, który w chwili przesłuchania nie ukończył 15 lat, planowana pora i czas przesłuchania powinny uwzględniać potrzeby wynikające z jego wieku, potrzebę nawiązania z nim kontaktu przez biegłego psychologa przed przystapieniem do przesłuchania oraz potrzebę ewentualnych przerw w prowadzonej czynności.

\section{Utrwalanie czynności przesłuchania — protokół, rejestracja obrazu i dźwięku, stenogram}

Protokół nie może stanowić jedynej formy zabezpieczenia niewątpliwie trudnej i złożonej czynności procesowej, jaką jest przesłuchanie małoletniego pokrzywdzonego w sprawach przeciwko wolności seksualnej i obyczajności. Podkreśla się, iż nie potrafi on oddać nastroju przesłuchania, zachowań przesłuchującego i przesłuchiwanego, ich brzmienia gło- 
su, mimiki; niemożliwe jest także ujęcie w nim emocji, jakie towarzyszą składanym oświadczeniom dowodowym. W rezultacie nawet najbardziej skrupulatne odnotowanie komunikatów pozawerbalnych nie odtworzy klimatu, jaki towarzyszy przeprowadzanym czynnościom ${ }^{36}$.

W myśl art. 147 § 2a k.p.k. — dodanego ustawą nowelizującą z dnia 13 czerwca 2013 r. - przesłuchanie pokrzywdzonego, o którym mowa $\mathrm{w}$ art. 185a i art. 185c, oraz świadka, o którym mowa w art. 185b, utrwala się za pomocą urządzenia rejestrującego obraz i dźwięk. Taki też wymóg wprowadzają dyrektywy Parlamentu Europejskiego i Rady w sprawie zapobiegania handlowi ludźmi i zwalczania tego procederu oraz ochrony ofiar z dnia 5 kwietnia 2011 r. (art. 15 ust. 4); w sprawie zwalczania niegodziwego traktowania w celach seksualnych i wykorzystywania seksualnego dzieci oraz pornografii dziecięcej z dnia 13 grudnia 2011 r. (art. 20 ust. 4) oraz ustanawiająca normy minimalne w zakresie praw, wsparcia i ochrony ofiar przestępstw z dnia 25 października 2012 r. (art. 24 ust 1 lit. a), w myśl których Państwa członkowskie podejmują środki niezbędne do zapewnienia, by w sprawach przez nie określonych, lub w odpowiednich przypadkach przesłuchania dziecka występującego jako świadek mogły być utrwalane audiowizualnie $\mathrm{i}$ by te utrwalone audiowizualnie przesłuchania mogły zostać wykorzystane jako dowód w postępowaniu przed sądem karnym, zgodnie $\mathrm{z}$ regułami przewidzianymi w prawie krajowym.

Z treścią przepisu art. $147 \S 2 \mathrm{a}$ k.p.k. skorelowany jest wprowadzony w art. 185a $\S 3$ k.p.k. obowiązek odtworzenia na rozprawie głównej sporządzonego zapisu obrazu i dźwięku przesłuchania małoletniego pokrzywdzonego w sprawach, o których mowa w art. 185a § 1 k.p.k., poza odczytaniem protokołu. Audiowizualne utrwalenie przesłuchania małoletniego zapewnia realizację zasady bezpośredniości, pozwala na zapoznanie się z mimika, gestami oraz wszelkimi innymi (nie tylko słownymi) reakcjami przesłuchiwanego na zadawane pytania, co ułatwi sądowi ocenę nie tylko okoliczności, ale i skutków popełnionego na szkodę małoletniego przestępstwa ${ }^{37}$.

36 J. Mierzwińska-Lorencka, op. cit., s. 177.

37 Zob. A. Krawiec, Małoletni pokrzywdzony w polskim procesie karnym, Toruń 2012, s. 171-172. 


\section{Wnioski}

Reasumując, nowelizację wprowadzoną ustawą z dnia 13 czerwca 2013 r. o zmianie ustawy - Kodeks karny oraz ustawy - Kodeks postępowania karnego ocenić należy pozytywnie. Proponowane przez nią rozwiązania co do zasady wzmacniają standardy przesłuchania małoletnich ofiar przestępstw przeciwko wolności seksualnej i obyczajności, chronią je poprzez możliwość zastosowania takich środków jak np. uzależnienie dopuszczalności składania zeznań od tego, czy mają one istotne znaczenie dla rozstrzygnięcia sprawy, utrzymanie zasady jednorazowego przesłuchania, przy jednoczesnym dążeniu do ograniczenia sytuacji, w których konieczne jest ponowne przesłuchanie małoletniego pokrzywdzonego z powodu nieposiadania obrońcy przez oskarżonego w czasie pierwszego przesłuchania małoletniego (wyznaczenie obrońcy z urzędu, gdy oskarżony nie posiada obrońcy z wyboru), czy możliwość udziału w przesłuchaniu osoby pełnoletniej wskazanej przez pokrzywdzonego.

De lege ferenda postulować należy rozważenie przez ustawodawcę wprowadzenia unormowania, by ponownego przesłuchania małoletniego pokrzywdzonego przestępstwem przeciwko wolności seksualnej i obyczajności - w miarę możliwości — dokonywał ten sam sędzia. Wprowadzenie takiego rozwiązania niewątpliwie spowodowałoby zminimalizowanie stresu związanego z przesłuchaniem, jak również - na co zwraca uwagę Sąd Najwyższy w swojej opinii do projektu ustawy o zmianie ustawy Kodeks karny oraz ustawy Kodeks postępowania karnego z dnia 24 stycznia 2013 r. - mogłoby przyczynić się do wyspecjalizowania się pewnej kategorii sędziów w przesłuchaniach tego rodzaju pokrzywdzonych, które ze względu na swoją specyfikę z pewnością wymagają mniejszej rutyny, odpowiedniego przygotowania i stosownej wiedzy psychologicznej ${ }^{38}$. Uwagę tę można także odnieść do psychologa, który uczestniczy w przesłuchaniu małoletniego, prowadzonym w trybie art. 185a k.p.k.

38 Opinia Sądu Najwyższego z dnia 24 stycznia 2013 r. do projektu ustawy o zmianie ustawy - Kodeks karny oraz ustawy - Kodeks postępowania karnego, http://www.sejm. gov.pl/Sejm7.nsf/druk.xsp?documentId=1E7B0DFE39EAFB01C1257B080045116A (dostęp: 31.12.2014).

Nowa Kodyfikacja Prawa Karnego 39, 2016

(C) for this edition by CNS 


\section{Protection of a minor victim under the penal law in cases concerning crime against sexual freedom and morality - a few comments against the background of the amendments introduced by the updated Act dated 13 June, 2013 Amending the Act — The Penal Code and the Act — The Criminal Procedure Code}

\section{Summary}

The article discusses issues linked with the protection of a minor victim in cases against sexual freedom and morality in the context of amendments introduced by the Act dated 13 June, 2013 Amending the Act — The Penal Code and the Act - The Criminal Procedure Code which took effect on 27 January, 2014 and introduced major amendments into the Criminal Procedure Code including the content of Art. 185a of the Criminal Procedure Code regulating the manner of examination of a minor victim who at the moment of the hearing is under 15 in proceedings concerning crimes referred to therein, among other things in the proceedings against sexual freedom and morality.

Subject to analysis, particularly in the context of the aforesaid amendments, are the following issues:

- scope of application of the regulations of Art. 185 a of The Criminal Procedure Code,

- principle of single time examination of a minor victim in cases concerning crimes against sexual freedom and morality,

- authority with a legal entitlement to interview a minor victim and other entities participating in the examination,

- strategy for interviewing a minor victim in light of the Regulation of the Minister of Justice dated 18 December 2013 on the Preparation of the Interview Carried out in the Manner Referred to in Art. 185a-185c of the Criminal Procedure Code and the rules for recording the examination.

Keywords: protection of a minor victim, examination of the minor, crimes against sexual freedom and morality, secondary victimisation. 